\title{
Vygotsky and the Theories of Emotions: In Search of a Possible Dialogue
}

\author{
Vygotsky e as Teorias das Emoções: Em Busca de um Possível Diálogo
}

\author{
Giovana Reis Mesquita* \\ Universidade Federal da Bahia, Salvador, Brasil
}

\begin{abstract}
The purpose of this article is to articulate Vygotsky's theoretical conceptualizations on Historical-Cultural Psychology with studies on emotions. The text emphasizes Vygotsky's theories on the development of higher psychological processes and mediation of signs in its constitution. We propose a way of understanding emotions based on the historical-cultural approach, starting from a plausible analogy with Vygotsky's ideas on thinking and language. Finally, the construction of such idea on the development of emotions is confronted with research and theories in the field of neuroscience and evolutionary psychology. It was done in order to establish an integrated view of the phenomenon and argue that Vygotsky's theory may continue to generate new knowledge in various fields, such as emotions.

Keywords: Vygotsky, theory of emotions, emotions.

Resumo

Este artigo procura articular as conceituações teóricas da Psicologia Histórico-Cultural de Vygotsky com estudos sobre emoções. O texto enfatiza as teorias de Vygotsky sobre o desenvolvimento dos processos psicológicos superiores e a mediação dos signos na constituição desses. É proposta uma forma de entendimento das emoções com base na abordagem Histórico-Cultural a partir de uma analogia plausível com as ideias sobre pensamento e linguagem. Por fim, a construção de tal ideia sobre o desenvolvimento das emoções são confrontadas com pesquisas e teorias no campo da neurociência e Psicologia evolutiva buscando-se estabelecer uma visão integrada do fenômeno e argumentar que a teoria de Vygotsky pode continuar gerando novos conhecimentos em diversos campos de estudo, tal como o das emoções.

Palavras-chave: Vygotsky, teoria das emoções, emoções.
\end{abstract}

Perhaps one of the most complex issues within psychology is the study of emotions. Despite the undeniable existence and proof of the existence of the emotional phenomenon, to establish its boundaries and variables seems to be a very complex task, whose results are not always consensual. When Gondim and Álvaro (2012) systematized the literature currently being produced in this area, they observed that advances in studies on the subject have shown the need to search for an integrated view.

Accordingly, this article explores Vygotsky's theory as another attempt to understand the phenomenon of emotions, integrating biology-culture-individual from a plausible analogy with his ideas about thought and language, as he described the process of psychic functions superiors. In his work, there is not an explicitly and

\footnotetext{
"Endereço para correspondência: Departamento de Psicologia, Faculdade de Filosofia e Ciências Humanas, Universidade Federal da Bahia, Estrada de São Lázaro, 197, Federação, Salvador, BA, Brasil 40210-730. E-mail: mesquitagr@hotmail.com
}

systematically organized theory of emotions, yet it is believed that there is a consistent theoretical legacy for understanding psychological phenomena.

Vygotsky had a bold intention in Psychology, which was of establishing a unifying theory of dialectical materialist basis. But certainly his untimely death (at age 37) did not allow the further development of the theme of emotion.

The author has produced a vast psychological theory known as Historic-Cultural Theory, grounded in the social formation of the individual. According to this approach, psychological is originated in the concrete dimension in which it is inserted, and is not the exclusive result of a human "nature". This social view of the psychological phenomenon legitimates itself with great force in Soviet psychology influenced by Marxism (Gonzalez-Rey, 2000). The individual is seen as being constituted in the interaction of its activities in the cultural context. In these relationships, the subject acquires specific instruments of language and thought which enable him/her act in the world not only based on information received from the sensory organs. 


\section{Thought and Language}

This is the crucial binomial to the understanding of human consciousness in the work of Vygostsky. Thought is prior to language, but the acquisition of the latter causes a profound change in the former. That is, the psyche takes very specific properties, with new categories of thought. Thus, it can be said that the development of higher mental functions occurs through the mediation process. And where is emotion in this social process of construction of the human mind?

At first glance, it looks like the work of Vygotsky excluded the study of human emotions. What has been explicitly known of his thinking boils down to an incomplete manuscript, written between 1931 and 1933, in which Vygotsky (1930/1998) negatively evaluates the theories of James and Lange, when they subordinate to the emotions to biological reactions. For the author, the mere biological utility is not able to explain the variability and the increase of emotions throughout the historical development of humans, therefore going against this understanding, which was based on a naturalistic view.

To Sawaia (2000), the topic of emotion is diluted across Vygotskian work as an epistemological and ontological question, central to his theory. For the author, what happens is that the theory of emotions is an underexplored part of Vygostsky's work by its scholars, influenced perhaps by rationalism. In fact, Vygotsky gives to emotion a character similar to cognitive processes, as constituent of units of the psyche, but the term emotion appears dispersed in his work (Gonzalez-Rey, 2000), not as a theory systematically formulated.

Importantly, Vygotsky makes use of different expressions for the phenomenon in question: passion, affection, emotion and feeling, as pointed Magiolino (2010) and Veresov (2009). In surveys of different studies on emotions, Magiolino (2010) and Sawaia (2000) highlight the variety of definitions and the difficulty in establishing a single meaning, able to include all its facets. Gray and Watson (2001), for example, make a differentiation of concepts such as emotion, feeling, mood and temperament, placing them as distinct affections characterized by duration, object, frequency and state.

In the case of Vygotsky's work, adds to that the very process of translation of the Russian original, which could cause misunderstandings or variations of words for the same term in a particular language, besides, of course, the unfinished character of his work, a theory in construction, often written in the form of drafts. Yaroshevsky (1987) examines the issue and proposes the term emotion as the corresponding to the words affection and sentiment, which also appear in his writings. We will, therefore, deal with the theme emotion and its related terms in the work of Vygotsky, whose argument will focus here on its development, following the general laws of transformation within the tradition of Marxist dialectical thought, and their relationships and integrations with evolution, culture, biology and semiotic mediation.
In one of his first works, Vygotsky (1926/2003) states that "anyone who thinks that emotion is a purely passive experience of the body and it does not cause any activity is designing the question in a wrong way" (p. 118). He adds that emotions are generating and organizing internal reactions of human behavior. In the text, "The problem of Research and Method", Vygotsky (1934/1999) criticizes the dualistic tendency in psychology to separate intellect from affection. He states:

Admitting that thought depends on the affection is not much to do, we need to go further, go from metaphysical study to the historical study of phenomena: it is necessary to examine the relationship between intellect and affection, and the relationship of these with the social signs, and avoiding reductionism dualisms. (p. 121)

This demonstrates that the author regarded the affection as part of the psychic functions, and not an isolated cognition entity. It confirms, however, that although the concept of emotion is not explicitly recorded in his work, and therefore there is not a theoretical body organized for this purpose, this subject is approached on diverse subjects such as art (Vygotsky, 1923/2001), pedagogy (Vygotsky, 1926/2003) and child development (Vygotsky, 1930/1998). In Theory of Emotions (Vygotsky, 1931/ 2004), one of his last works, the author addresses how psychology was dealing with the subject and its relationship with the Cartesian philosophy. Thus, Vygotsky did ignore emotions, but surely stopped working this issue more systematically.

The work of Magiolino (2010) makes a detailed and thorough study of the elaborations of Vygotsky about emotions and points Spinoza, Freud and Marx as his main interlocutors. The author argues further that the central issue of the theme in his work is the development of emotions by semiotic mediation in individual historysocial. In this context, this article seeks to advance the theories and concepts about emotions, proposing an integrated study in the field, following the same theoretical bases of Vygotsky's production on thought and language.

\section{Historical-Cultural View of Human Development}

Based on the theoretical framework of HistoricalCultural Psychology, the process of psychological development is seen as dependent on contact with each other and the acquisition of linguistic mediational instruments. This conception of development differs from innatist and maturational conceptions because human subjectivity is not just the result of biological processes, since it needs to be "built". Thus, consciousness has its genesis grounded in social environment; it is language acquisition that leads to a transformation of the structure of mental functions, as it creates a dialectical unity with thought.

According to Vygotsky (1933/2000), when the child is born he/she is only endowed with a practical conscience, like other primates. His/her world view is closely linked 
to information that reaches him/her through the senses: he/she does not prescind real objects. His/her psychic functioning is elementary, conditioned by genetic potential and the constraints of survival of the species in the environment, called the lower psychological processes.

The quantum leap in human development, which frees humans from immediate perceptual data, happens with the emergence of what Vygotsky called higher psychological processes. Such processes include the human ability to abstract, to prescind objects, to establish logical relations and all other cognitive functions, inherent only to humans.

The passage from one to the other process does not occur spontaneously. For Vygotsky (1930/1993), this jump occurs through language acquisition, by establishing a position with the mediated world. So, we can say that, with the help of the indicative function of words, the child begins to control his/her attention, creating new structural cores.

Vygotsky (1930/1993) points out that language does not originate thought, because thought already exists in its rudimentary form since child is born. Thought and language, therefore, do not have a common origin, are not of the same nature, but the acquisition of the latter causes a change in the quality of thought. That is to say that the use of artificial means acquired socially transforms psychological operations. The world of experience needs to be simplified, related and generalized before it can be translated into code, implying a breakthrough in the development stage of thought. Also according to the author (Vygotsky, 1933/2000): "the moment of greatest significance in the course of intellectual development, which gives rise to the purely human forms of practical and abstract intelligence, occurs when speech and practical activity, then two lines completely independent development, converge" (p. 33).

If language has the power to create more complex forms of thought, and if its origin is subject to the need for dialogue and agreement among humans, it can be said that individual consciousness arises from relationships between humans. The psychological phenomenon stops, accordingly, to be taken as an abstract entity, and starts to be understood as built and builder of concrete social relations of existence.

Studies in neuroscience, in the area of brain plasticity, have collaborated to ratify the idea proposed by Vygotsky about the social construction of mind. According to Johnson (1999), plasticity is regarded as a property inherent to brain development that involves a process of increasing specialization in morphology and function of tissues and neuronal cells. For both, just one genetic plan for brain development is not enough, plasticity ensures that there needs to be more complex interactions to enroll new functions. Plasticity means that the brain is not "ready", it is not given in advance, but there is a space to be worked on and built that provides an increase in its functional extension, and such space refers to the in- fluences of the environment, the interactions that the subject performs in the postnatal period.

Thus, social interaction is necessary in order to establish new structures of thought, as Vygotsky proposes in his work. The subject is completed and becomes a being endowed with complex consciousness because of his/her symbolic apprehension acquired by being in contact with others. In this sense, biology and culture are in a reciprocal relationship of determination. We then have a compatible explanation which somehow integrates Vygotsky's theory on development of thought and the biological nature preparing the cortex for roles to be filled, thought the insertion of the individual in social interactions.

That argument seems to point efficient possibilities for solutions to the dead-lock between nature and culture, faced by psychology as a science since its founding. For it does not place the individual as predominantly cultural nor as entirely programmed by nature, but rather as a being that is formed by the dialectical relationship between these two poles of development. Based on this view, it is believed to be possible to make some observations on the character and development of human emotions, complying with the new studies produced in this field, creating thus a possibility of producing integrated knowledge of the phenomenon.

\section{Emotion from the Evolutionary Point of View}

We can say that emotions are not unique because we are able to classify different emotional states, therefore they are also a universal psychological process, since they are inherent to all human beings. Here lies its great importance in the study of humanities and more particularly, in psychology. However, the consensus ends there, for defining and establishing the nature and limits of emotions has been a complex task of multiple and often incongruent results (Evans, 2003).

Studies with children, who less "contaminated" by symbols, values and cultural meanings, can provide a good explanation for the natural character of emotions. And what can be seen, according to Parkinson, Fischer and Manstead (2005), is that children have a limited repertoire of emotions visibly manifested. In fact, it is impossible to know whether the child from an early age has emotions like guilt, jealousy or shame because he/she are not endowed with the linguistic apparatus to express inner states.

Ekman's research (1952, cited by Evans, 2003) are congruent with the idea of an innate and restricted emotional repertoire, they propose six universal basic emotions: happiness, sadness, anger, fear, surprise and disgust. The methodology of this study used facial expressions corresponding to each emotion and there was a consensual recognition by adults of diverse cultures. Although there are disagreements about what are the basic emotions, as Evans points out (2003), the idea that there are innate emotions that were selected during the evolution of the 
species, and therefore common to all humans seems to prevail.

Now, speaking of innateness and universality, opens up space for an understanding of the evolutionary phenomenon, concerned with the beginning and the functionality of behaviors acquired by the species. According to Oliva et al. (2006), Evolutionary Psychology brought to the scene the study of emotions, relegated hitherto to a marginal role for cognitive theories - which perceived mind as equivalent to reason and logic - and behaviorists - for whom the only valid scientific study is one of socially observable behavior. Yet according to the authors, the evolutionary bias understands emotions play an extremely important role, acting as a "super-ordered programs" that coordinate other cognitive functions efficiently and smoothly. Thus, we can say that emotions act as filters that guide attention and select the inputs required for the regulation of adaptive behavior.

The evolutionary character of Vygotsky's thinking (1926/2003) can be observed when he credits to emotions a biological adaptive role, since they enable, for example, a rapid escape in times of danger. In line with this thinking, researchers Wentworth and Ryan (1992) argue that emotions were the original mode of communication between our immediate ancestors, with two powerful features for the survival of the species: quickly warn and guide us and strengthen social ties through emotional identification.

Turner and Stets (2005) present three recent studies on evolutionary theory and emotion and they all agree that emotions are a key force in maintaining and forming social bonds. And, to resume Vygotsky's theory about the importance of social interaction in the formation and development of the human psyche, we find, again, a dialectical relationship of determination between nature and culture upon which such evolutionary studies confirm. Wentworth and Ryan (1992), for example, emphasize the socially constructed character of emotions, but at the same time, recognize the physiological basis of emotional systems. In other words, emotions are meant to meet social demands, but are supported by a biological basis. Further according to the authors, the cognitive abilities of humans let us able to construct an emotional repertoire which goes beyond the primary. And we can say that this game of social interactions, placed in a dialectical understanding, leads to the establishment of new social needs that require the perpetuation and complexity of emotions.

The study by Turner (2000) confirms, in some sense, the idea of the necessity of the emergence of emotions for the species and its dialogue between nature and culture. According to the author, living in society would be an alternative for humans to survive, hence, natural selection re-arranged the human brain to highlight the emotions and these can be used in raising the level of social organization.

Evolutionary theory has made important contributions on the functionality of primary emotions, which may have a predominantly universal character, regardless of culture. However, Niedenthal, Krauth-Gruber and Ric (2006), when addressing the possibilities for studies of general emotions (and not just the basic or primary), problematize, too, the difficulty of evolutionary psychology to explain how the same phenomenon can cause different emotions in the same species.

\section{Emotion and the Cultural Viewpoint}

Empirical findings, systematized by Niedenthal et al. (2006), show the variety and emergence of new emotions, throughout the history of each society. In reviewing research on linguistic framework, they also observed cultures that have less semantic repertoire to describe emotional states and others with more. Supporting this research, studies raised by Parkinson et al. (2005), show that, in the English language there are about 2000 words to describe emotional states, whereas in the aboriginal language of central Malaysia, there are only seven.

The analysis of cultural differences in the language of emotions, as a rule, shows that most human states serve the goals of each society. Thus, there is an inexorably intrinsic character between emotion, the words used to designate them and the historical-cultural reality.

For Parkinson et al. (2005), also based on empirical findings, facial expressions are best recognized by members of the same culture, because they are more familiar to the codes of their group. Elfenbein and Ambady (2002) found that recognition of expressions of fear and disgust are more subject to cultural variation than, for example, happiness. These findings lead to the reflection that, even as a mental phenomenon, expressed by the subject, emotions need rules of social use (words and meanings) to be capable of understanding.

Thus, in studies of emotions, there is also room for the changes, when they are seen as dependent on each individual's particular history and social development. This issue drives the understanding of emotional phenomena as closely dependent on the cultural, detaching it from an understanding merely based on genetics.

There is still a polarized debate between the relationships of emotional experience and its representation to a culture; this remains as an issue not fully understood. Some psychologists, favorable to universal emotions, do not believe in cultural variation, restricting its influence only to ideology and interpretation of emotion, but not the emotional experience itself, as highlighted Manstead and Fisher (2002).

Comparative research has found similarities and variations between cultures in emotional representations (Brandt \& Boucher, 1985; Mesquita \& Frijda, 1992; Scherer \& Wallbott, 1994), which leads the discussion to an understanding of the complex and dynamic phenomenon. Accordingly, Manstead and Fisher (2002) point out that the main concern should be on the extent to which 
cultural variation occurs in the emotional field, instead of the impasse between innate or acquired.

Consistent with these issues, Vygotsky (1934/1999) in

"On Psychological Systems" demarcates what he understands as the cultural influence on emotions:

The fact of thinking in affections, placing them in other relationships with my intellect and elsewhere, consistently changes my psychic life. In simple terms, our affections act in a complicated system with our concepts, and one who does not know that the jealousy of a person related to Mohammedan concepts of fidelity regarding women is different from one coming from other people related to a system of opposing concepts about the same thing, does not understand that this feeling is historic, that it actually changes in different psychological and ideological means although in it remains undoubtedly a certain biological radical under which this emotion arises. (p. 127)

According to Manstead and Fisher (2002), there is growing consensus among psychologists that the emotional language is an important issue in cross-cultural research. That is, we can argue that the proviso that Vygotsky made about the symbolic apparatus, interfering with specific emotional experiences, is still an idea that remains current and corroborated by further studies.

Vygotsky (1930/1998), decades ago, had already paid attention to the development and differentiation of emotional repertoire between, for example, the early stages of infant development and adult man and woman. According to the author, it would not be possible to reduce emotions to a biological usefulness, because by doing so it would not be possible to explain how the world of emotions is modified at each new step in the historical development of humans. Thus, Vygotsky (1934/1999) was aware that emotions are not static, but change historically and ontogenetically: "complex emotions appear only historically and are a combination of relationships that arise as a result of historical life, that combination occurs in the course of the evolutionary process of emotions" (p. 127).

Confirming these ideas, Elias (1990), in his sociological study of what he termed the "civilizing process", argues that inasmuch as societies dense relations among their subjects, creating more interdependence between them, a gradual process of increasing the control of emotions was observed. Each individual is forced to consider the effect of his/her actions or the actions of others on a range of social relationships in the chain. More civilized and complex societies place the subject as depending on the activities of a growing number of people, so the subject is also incomparably more limited in his/her behavior, in the possibility of giving immediate satisfaction to his/her tendencies and impulses.

Following the reasoning proposed by Elias (1990), emotional states have a markedly social and historical origin. The possibility of understanding emotions only thorugh an innatist view, from which all mankind would have the same emotional framework, is placed in check, What can be argued, therefore, is that there is an intrinsic character between emotion and historical-cultural reality, which is pervaded by specific modes of thought.

In his writings on pedagogy, Vygotsky (1926/2003) establishes a dialogue between emotion and cognition, arguing that intellectual feelings (such as interest, curiosity, awe) are a result of the way thinking conducts emotions. Here we see a proposal for understanding the existence of a relationship between cognition and other types of emotion, but not yet put into a dialectical relationship, as noted later in his work, regarding the issue of thought and language.

\section{Emotion and Cognition: Neuropsychological Contributions}

For over a century, neuroscientists recognize the brain as an open and adaptive system, influenced by the experiences of the body with the external environment. More recently, empirical studies being conducted show the functional development of the brain in line with the experiences of each subject ( $\mathrm{Li}, 2009)$. In other words, we can see how experiences and cultural facts inculcate con-crete changes in the cerebral apparatus.

According to Evans (2003), thought does not generate excitement and vice versa, before they act concurrently. There is not emotion without cognition nor emotional state that is not permeated by perception. Niedenthal et al. (2006), supported by empirical data, say that cognition plays an important role on emotional experiences. Damásio (2006), who conducts studies on the human brain and its relations with various observable behaviors, states that " feelings are just as cognitive as any other perceptual image and as dependent on the cerebral cortex as any other image" (p. 190 ). Quite similar idea is presented by Vygotsky (1934/1999) when he states that:

The way of thinking, one which, together with the system of concepts was imposed on us by our surroundings, also includes our feelings. We do not simply feel: feeling is perceived by us in the form of jealousy, anger, outrage, and offense. If we say we despise someone, the act of naming feelings causes these feelings to vary, as they maintain a certain relationship with our thoughts. (p. 126)

It is through cognition that we name the world, is also through cognition that we learn to name the emotions and broaden the scope of what is felt. There is talk of expanding this notion because we can say that emotion is prior to a more accurate cognition. Or we can argue that the primary emotion is prior to what Vygotsky called the higher psychological processes. Damásio (2006) similarly distinguishes between what he calls primary emotions universal and restricted to responses of the body, dependent on network circuits of the limbic system, particularly the amygdala - and the secondary or social - more complex and related processed representations acquired by the 
prefrontal cortex. It seems, therefore, clear that there are two kinds of emotions: the primary kind - of a genetic and universal character - and the secondary kind dependent on social learning and therefore a process wherein cognition is intrinsically related.

Let's think, for example, in a very social emotion quite easily verifiable, such as shame. A subject may be ashamed, for example, for thinking bad about the attitude of a particular coworker and get even blush. Now, that emotion does not appear naturally, but depends on a social understanding that is, in turn, learned in contact with others. Only when one has a developed cognition, one can feel an emotion such as shame, because we must learn a set of concepts and social norms.

Thus, it would not be erroneous to say that cognition affects emotion, insofar as cognition can create certain emotional states which are more complex, according to the life history of each individual and with the standards developed by the specific milieu in which one is inserted. Consistent with the foregoing, Damásio (2006) states that:

it does not seem sensible to me to exclude emotions and feelings from any general conception of the mind, even though it is exactly what many scientifically respectable studies do when they separate emotions and feelings from treatment of cognitive systems (p. 189).

Studies of the brain amygdala have given important contributions to the biological understanding of brain markers on the relationship between cognition and emotion, as Phelps (2006) shows. His conclusion is that the classical division between emotion and cognition may be unrealistic and that the understanding of human cognition requires consideration of emotion.

The amygdala influences cognitive functions in response to emotional stimuli. There are several studies looking at the role of the amygdala in the interaction of emotion and cognition, such as: emotional learning, emotion and memory, influence of emotion on attention and perception, emotional processing in social stimulus and change in emotional responses (Phelps, 2006). An example of this relationship is given by EsperidiãoAntonio et al. (2008) as they state that the stimuli that reach the brain go through limbic structures in order to acquire emotional significance and then are directed to regions of the cortex (where rational thought is) so that decisions and actions are taken.

Johnson (1999) argues that it is in the prefrontal cortex that more complex cognitive processes occur, this is the area where the highest skills are, such as planning and executing action sequence and previous judgment. The author also states that the frontal cortex is associated with individual differences in the expression of emotions. By logical deduction, if cognition is developed, as shown, for example, in the experiments of Piaget, emotions must also be subject to development, since they are biologically and functionally related.
Phelps (2006) shows a relationship between the amygdala and cortical regions of the brain. When the amygdala works harder - in conditioned and automatic stimuli - there is less involvement of cognition. On the other hand, in instructed fear, there is a greater work of cortical areas than of the amygdala.

As ratified by Parkinson et al. (2005), there is a group of genetically programmed basic emotions selected by evolution, whereas other emotions, called secondary, develop during socialization with the function of cognitive articulation. They are more subject to cultural influence and have a difference brain correspondence when compared to primary emotions.

Finally, we can conclude that the amygdala, sub-cortical area, is more associated with primary and automatic emotional states, and more connected to humans' innate nature, whereas cortical areas work in emotions which are not provided beforehand and that, therefore, seem to have nothing to do with natural selection of species, but rather with the learning and social rules. Here is a quite plausible relationship between certain emotions, culture and cognition.

\section{Vygotsky and the Study of Emotions: A Possible Dialogue}

When Parkinson et al. (2005), conducted a survey on the studies of cultural variation in emotions, they concluded that in this field of knowledge, the most important issue is no longer whether emotions are universal or result of cultural influences, for now it is known that both dimensions interact in a complex way. The question - which remains insoluble for authors - is the extent to which these two dimensions relate and what are the processes underlying this relationship.

In this sense, Vygotsky's theoretical framework offers a space for constructing thinking about the emotions towards an understanding of the dialectical relationship between nature and culture. Based on his theoretical framework, the process of psychological development is seen as dependent on the contact with others and the acquisition of linguistic mediational instruments. Thus, human psyche is the result of the relationship biology-culture-environment, breaking with the developmental view that usually establishes a unidirectional causal relationship, moving always from biology to culture.

In the field of emotions, one can draw a parallel reasoning between thought and language, as Vygotsky proposed. Taking up the ideas already mentioned here, we saw that the child, when born, is endowed with thought, but a practical thought, very focused on a concrete relationship with the environment. Similarly, the same way are the child's innate emotions: basic, somewhat elaborated, common to all human beings, composed of standardized facial expressions and, therefore, have a distinctly biological determination. 
Now imagine an adult who has only basic emotions which are only six. We can think about how difficult his/ her life on the planet would be, and despite his/her feelings may be known by any individual of any culture - since basic emotions are universal - he/she would have an immense difficulty to establish a relationship with anyone, for he/she would not understand the emotional frameworks specific to each culture.

It is clear, therefore, that there are emotions that depend on social learning to be expressed and understood. Let's call these emotions secondary emotions, due to their cultural and cognitive load. They are emotions that need a contact with language and, consequently, with meanings and symbolic exchanges with the social environment.

A "very high activity of the psyche" (Vygotsky, 1923/ 2001) and the process of fantasy are nothing but activities pertaining to higher psychological processes, dependent on the linguistic apparatus to form. So we can say that, as thought, emotion has a different nature and origin of language. In fact, in his article of 1929, "Basic Problems of Modern Defectology", Vygotsky (1929/1997) sees emotion and cognition with relative independence in their origins, just like he later formulated in more detail about thought and language. Thus, one can argue that when the emotional system meets language, there is a qualitative leap in the former. This leap is like the secondary, or higher, emotions: humans acknowledge themselves only after they belong to a cultural milieu.

Thus, emotions go through the same dialectical process cognition goes: both are committed to changing needs that accompany psychological development as a whole. To Gonzalez-Rey (2000), is the emergence of new psychological needs that engender qualitatively different emotions, and in turn, these emotions lead to the emergence of new needs. He adds:

... affection, which is constructed through categories of emotion and need as well as through feelings, is a constituent aspect essential to the psychic system, within which these processes, both cognitive and affective, do not operate in isolation but as moments of a complex system, which Vygotsky places at different times of his work, in development, in personality and in consciousness. (p. 143)

The difficulty in establishing which are actually the primary emotions (Evans, 2003) may come from the fact that it is difficult to precisely classify what is primary after higher emotions settle, change and re-arrange in the psychic whole. Just as it is difficult to identify in adult men and women which are actually lower psychological processes. After a certain level of development, it becomes difficult to select earlier developmental stages in current behaviors, because as stated by Vygotsky in his work, the development is not cumulative, there is not a quantitative change from one phase to another, but rather qualitative. The human psyche is seen, therefore, as a whole, not restricted to a sum of acquisitions and psychological performance. Thus, studies with babies - who have not yet developed higher psychological processes, since they did not learn language yet - seem to be the most suitable for the task of knowing about the primary emotions.

For historical-cultural psychology, humans are not born ready, our development depends on our contact with the social environment, which will provide the acquisition of the tool for semiotic mediation and thus cause a qualitatively different psychic configuration in our innate dispositions. In this sense, social environment also serves on the emotional field, offering not only names to what is felt, but also creating emotions, according to standards and social needs. Therefore, to speak of emotions is to speak of their meanings: individual and collective ones.

\section{References}

Brandt, M. E., \& Boucher, J. D. (1985). Judgements of emotions from the antecedents situations in the three cultures. In I. R. Lagunes \& Y. H. Poortinga (Eds.), From a different perspective: Studies of behavior across cultures (pp. 368342). Lisse, The Netherlands: Sweets \& Zeitlinger.

Damásio, A. (2006). O erro de Descartes. São Paulo, SP: Companhia das Letras.

Elfenbein, H. A., \& Ambady, N. (2002). On the universality of cultural specifity of emotion recognition: A meta-analysis. British Journal of Psychiatry, 174, 444-448.

Elias, N. (1990). O processo civilizador: Vol. 2. Lisboa, Portugal: Dom Quixote.

Esperidião-Antonio, V., Majeski-Colombo, M., ToledoMonteverde, D., Moraes-Martins, G., Fernandes, J. J., Assis, M. B. de, et al. (2008). Neurobiologia das emoções. Revista de Psiquiatria Clínica, 35(2), 55-65.

Evans, D. (2003). Emotion. A very short introduction. Oxford, UK: Oxford University Press.

Gondim, S. M. G., \& Álvaro, J. L. (2012). La emoción como fenômeno complejo y multifacético: el desafio de un abordaje integrado. Manuscript in preparation.

Gonzalez-Rey, F. (2000). El lugar de las emociones em la constituición social de lo psíquico: el aporte de Vigotski. Educação \& Sociedade, 70, 132-148.

Gray, E., \& Watson, D. (2001). Emotion, mood, and temperament: Similarities, differences and a synthesis. In R. L. Payne \& C. L. Cooper (Eds.), Emotions at work: Theory, research and applications for management (pp. 21-44). Chichester, UK: John Wiley \& Sons.

Johnson, M. H. (1999). Developmental Neuroscience. In M. H. Bornstein \& M. E. Lamb, Developmental Psychology: An advanced textbook (pp. 199-230). Hillsdale, NJ: Lawrence Erlbaum.

Li, S.-C. (2009). Brain in macro experimental context: Biocultural co-construção of lifespan neurocognitive development. In J. Chiao (Ed.), Cultural neuroscience (pp. 17-30). New York: Elsevier.

Magiolino, L. L. S. (2010). Emoções humanas e significação numa perspectiva histórico-cultural do desenvolvimento: Um estudo teórico da obra de Vigotski. (Tese de Doutorado nãopublicada). Faculdade de Educação, Universidade Estadual de Campinas, SP.

Manstead, A. S. R., \& Fischer, A. H. (2002). Culture and emotion. New York: Psychology Press.

Mesquita, B., \& Frijda, N. H. (1992). Cultural variations in emotions: A review. Psychological Bulletin, 112, 179-204. 
Niedenthal, P. M., Krauth-Gruber, S., \& Ric, F. (2006). What are emotions and how are they studied? In Psychology of emotion. Interpesonal, experiential and congnitive approaches (pp.1-49). Hove, UK: Psychology Press.

Oliva, A. D., Otta, E., Ribeiro, F. L., Lopes, F. A., Yamamoto, M. E., \& Seidl de Moura, M. L. (2006). Razão, emoção e ação em cena: A mente humana sob um olhar evolucionista. Psicologia: Teoria e Pesquisa, 22(1), 53-62.

Parkinson, B., Fischer, A. H., \& Manstead, A. S. R. (2005). Emotional meaning across cultures. In B. Parkinson, A. H. Fischer, \& A. S. R. Manstead, Emotions in social relations. Cultural, group and interpessoal processes (pp. 55-86). Hove, UK: Psychology Press.

Phelps, E. A. (2006). Emotion and cognition. Insights from studies of the human amygdala. Annual Review of Psychology, 57, 37-53.

Sawaia, B. (2000). A emoção como locus de produção do conhecimento: Uma reflexão inspirada em Vygotsky e no seu diálogo com Espinosa [Resumo]. In III Conference for Sociocultural Research. Campinas, SP: Universidade Estadual de Campinas. Retrieved from www.fae.unicamp.br/ br2000/trabs/1060.doc

Scherer, K. R., \& Wallbot, H. G. (1994). Evidence for universality and cultural variation of different emotion response patterning. Journal of Personality and Social Psychology, 110, 426-450.

Turner, J. H. (2000). On the origens of human emotions: A sociological inquiry into the evolution of human affect. Stanford, CA: Stanford Univesity Press.

Turner, J. H., \& Stets, J. E. (2005). The sociology of emotions. In Simbolic interactions theorizing on emotions (pp. 100-146). Cambridge, UK: Cambridge University Press.

Veresov, N. N. (2009). Forgotten methodology: Vygotsky's case. In A. Toomela \& J. Valsiner, Methodological thinking in psychology 60 years gone astray? (pp. 267-295). Charlotte, $\mathrm{NC}$ : Information Age.

Vygotsky, L. S. (1993). Pensamento e linguagem. São Paulo, SP: Martins Fontes. (Original work published 1930)

Vygotsky, L. S. (1997). Problemas de la defectologia moderna. In Obras escogidas: Tomo 5 (pp. 9-73). Madrid, España: Tomás Bretón. (Original work published 1929)

Vygotsky, L. S. (1998). O desenvolvimento psicológico na infância. São Paulo, SP: Martins Fontes. (Original work published 1930)

Vygotsky, L. S. (1999). Teoria e método em psicologia. São Paulo, SP: Martins Fontes. (Original work published 1934)

Vygotsky, L. S. (2000). A formação social da mente (J. Cipolla Neto, L. S. Menna Barreto, \& S. C. Afeche, Trads.). São Paulo, SP: Martins Fontes. (Original work published 1933)

Vygotsky, L. S. (2001). Psicologia da arte. São Paulo, SP: Martins Fontes. (Original work published 1923)

Vygotsky, L. S. (2003). Psicologia pedagógica. Porto Alegre, RS: Artmed. (Original work published 1926)

Vygotsky, L. S. (2004). Teoria de las emociones - estúdio histórico psicológico. Madrid, España: Ediciones Akal. (Original work published 1931)

Wentworth, W., \& Ryan, J. (1992). Balancing body, mind and culture: The place of emotion in social life. In D. Franks \& V. Gecas (Eds.), Social perspective on emotions (pp. 26-46). Greenwich, UK: JAI Press.

Yaroshevsky, M. G. (1987). Epílogo. In L. S. Vygotsky, The Collected Works of L. S. Vygotsky: Scientific Legacy. New 